DOI: $10.36910 / 6775-2524-0560-2020-40-08$

УДК: 004.048

Мартиненко Андрій Анатолійович, старший викладач, аспірант.

https://orcid.org/0000-0002-5033-4696

Мороз Борис Іванович, д.т.н., професор.

https://orcid.org/0000-0002-5625-0864

Гуліна Ірина Григорівна, к.т.н., доцент.

https://orcid.org/0000-0003-2565-5006

Сироткіна Олена Ігорівна, к.т.н., доцент.

https://orcid.org/0000-0002-4069-6984

Національний технічний університет «Дніпровська політехніка»

\title{
CONCEPTUAL MODEL OF AN INTELLIGENT DECISION SUPPORT SYSTEM TO IDENTIFY CULTURAL VALUES
}

\begin{abstract}
Мартиненко А.А., Мороз Б.І., Гуліна І.Г., Сироткіна О.І. Концептуальна модель інтелектуальної системи підтримки прийняття рішень ідентифікації культурних цінностей. В статті розглядається проблема розробки концептуальної моделі інтелектуальної системи підтримки прийняття рішень ідентифікації культурних цінностей, питання визначення основних сценаріїв роботи та обмежень. Також зазначається складність та комплексність підходу вирішення поставленої задачі, визначені перспективи та шляхи подальшого дослідження та використання даної предметної області.

Ключові слова: концептуальна модель, система підтримки прийняття рішень, інтелектуальний аналіз даних, ідентифікація культурних цінностей.
\end{abstract}

Мартыненко А.А., Мороз Б.И., Гулина И.Г., Сироткина Е.И. Концептуальная модель интеллектуальной системы поддержки принятия решений идентификации культурных ценностей. В статье рассматривается проблема разработки концептуальной модели интеллектуальной системы поддержки принятия решений идентификации культурных ценностей, вопросы определения основных сценариев роботы и ограничений. Также отмечается сложность и комплексность подхода решения поставленной задачи, определены перспективы и пути дальнейшего исследования и использования данной предметной области.

Ключевые слова: концептуальная модель, система поддержки принятия решений, интеллектуальный анализ данных, идентификация культурных ценностей.

A. Martynenko, B. Moroz, I. Hulina, O. Syrotkina. Conceptual model of an intelligent decision support system to identify cultural values. This paper addresses the issue of developing a conceptual model of an intelligent decision support system to identify cultural values as well as the definition of basic work scenarios and constraints. It also notes the complexity of the approach to solving the problem. Suggested routes for further research and usage of this subject area were also identified.

Keywords: conceptual model, decision support system, data mining, identification of cultural values.

Introduction. Problem statement. As noted earlier by the authors in works [1-3], the problem pertaining to research and development of methods and models is substantial. It involves organizing and processing data and associated knowledge in the intelligent decision support system (IDSS) to identify cultural values which are deemed to be relevant and offer a promising prospective. Despite the fact that such systems have been widely used in various fields (medicine, economics, automation and control, etc.), it should be noted that most tasks and problems in identifying cultural values have either just been formulated or are in the process [3]. This is due primarily to the peculiarities of this problem. The development of a conceptual model is one of the important stages in the creation of the relevant IDSS. It takes into account the specifics of the subject area and identifies the main elements of the system and the relationship between them, including the principles of their work.

Research analysis. The task of developing a conceptual model is closely related to various areas such as data and process analysis, artificial intelligence systems and the design and development of principles for the creation of DSS (Decision Support System). Classic works in this field are notably by T. Kravchenko, D. Pospelov, E. Popov, L. Zadeh, D. Waterman, O. Bakaev, Yu. Ulyanovskaya and others. The analysis of works in this area allows us to conclude that the conceptual model of the future IDSS (which takes into account the specifics of the subject area) is a key factor influencing the efficiency and quality of the system. Scientists and developers lay down the principles of the system and determine the basic concepts and criteria with which the system will work at the development stage of the IDSS model.

Previously unresolved parts of the problem. Today, there is no single, universal model for the construction of IDSS. This is due to the application of systems of this type imposing a number of relevant criteria specific to this subject area. It should be noted that the development of modern approaches and tools 
is also an important factor, and models developed previously will not be effective with these technologies. For example, a new model of IDSS should be developed for more efficient and high-quality work.

Aim of the work. The aim of this research is to improve the quality and efficiency of solving the problem of creating and using a modern IDSS by developing a conceptual model that will take into account the specifics of the subject area as well as modern methods and tools.

Main part. The decision support system is designed to support multicriteria decisions in a complex information environment. At the same time, multicriteria considers the fact that results of the decisions are estimated not on one, but on several sets of indicators (criteria) considered simultaneously. Information complexity is determined by the need to take into account a large amount of data the processing of which, without the help of modern information technologies, is almost impossible [4].

In works [5-7] the author notes that in Ukraine there is no national system to account for cultural values that include their registration and identification. As a result, there are a number of problems faced by professionals in the course of their activities. In order to allow the user to obtain information based on input data (and help to quickly and accurately assess the situation and make decisions), it is necessary to implement a computer-aided intelligence system. Furthermore, this system would assist users in making decisions in difficult conditions while providing a complete and objective analysis of the subject activity. Recently, scientists and researchers have promoted modern and effective methods and tools for identifying objects and building a modern IDSS. It should also be noted that modern solutions allow us to avoid or reduce a number of shortcomings that existed previously.

The work of IDSS is aimed at solving the following tasks: choosing the best solution from a set of possible and/or ordering possible solutions by preference (ranking).

In both tasks, the first and foremost factor is choosing a set of criteria, the basis of which further solutions will be evaluated and compared.

Different methods can be used for analysis and development of decisions (reports) in IDSS, for example: information search, data mining, the search of knowledge in databases, reasoning on the basis of precedents, simulation modelling, evolutionary calculations and genetic algorithms, neural networks, situational analysis, cognitive modelling, etc.

A decision support system is a set of software tools for data analysis, modelling, forecasting and management decisions.

When developing a model of IDSS, it is necessary to take into account the type of interaction between the system and the user, for example: passive systems assist in the decision-making process but cannot make a specific proposal or be directly involved in either making a decision or being involved in DSS interaction with the user. When a decision is offered by the system, the user can refine, improve, and return this decision to the system for verification. Following this, the decision is again issued to the user, then back to the system and so on until the user approves the decision. According to the authors, the most relevant and promising system is the active type of IDSS.

According to the method of decision support, the authors in their work assume that it is appropriate to consider and use DSS that are data-oriented and have access to the time series of the data organization and use in their work not only for internal but also for external data. Document-oriented DSS also manipulate unstructured information in a variety of electronic formats. Knowledge-oriented DSS provide specialized, evidence-based solutions to problems.

As for IDSS architecture, the authors in their work considered and used DSS based on a three-level data warehouse. Such DSS use a data warehouse from which data showcases are formed and are used by groups of users who solve similar tasks. This provides access to both specific structured data and single consolidated information. Filling the data showcases is simplified due to the use of verified and cleaned data in a single source. It should be noted a corporate data model also exists, and such DSS are characterized by guaranteed performance. However, a redundancy of data accumulates, leading to increased storage requirements. In addition, it is necessary to align this architecture to many areas with potentially different requests [2-4].

\section{Conceptual model.}

There are basic concepts with which the system works:

- object of identification is an identifiable object of cultural value (it has a description and criteria for analysis/identification);

- the user is an individual or legal entity, in the manner prescribed by law, who obtains the right of access to information in the IDSS; 
- access to information in the system gives the user the opportunity to process information in the system;

- information processing in the system is by implementation of one or more operations such as collecting, inputting, writing, transforming, reading, storing, removing, registering, receiving, and transmitting data which are carried out in the system using its hardware and software.

The above concepts are basic and are given to understand the operation of the system.

The authors consider it appropriate to organize role-based access control (RBAC) in the model developed for the system in which the access rights of subjects (users), and the information processed and stored in the system, are grouped. This takes into account the specifics of their application and forming roles $[8,9]$.

Role formation is designed to define clear and understandable rules for IDSS users of delimitation of access, thereby allowing us to implement a flexible and dynamic variable in the system rules. This approach should be used in systems for users whose official powers and responsibilities are clearly defined.

Since privileges are not assigned to users directly and are obtained by them only through their role (or roles), the management of individual user rights essentially comes down to assigning roles to this user. This simplifies operations such as adding a user or changing a partition by the user.

To determine the RBAC model, the following conditions are defined:

- $\mathrm{S}=$ Subject $=$ Human or automated agent (set of users);

- $\mathrm{R}=$ Role $=$ Work function or name defined at the authorization level (set of roles);

- $\mathrm{P}=$ Permissions $=$ Approval of the access mode to the resource (set of access rights to system objects);

- $\mathrm{SE}=$ Session $=$ Correspondence between $\mathrm{S}, \mathrm{R}$ and/or $\mathrm{P}$

$-\mathrm{SA}=$ Subject aim

- PA: $R \rightarrow 2 p-$ a function that defines a set of access rights for each role at the same time for each $p \in P$ there is $r \in R$ so that $p \in P A(r)$;

- $\mathrm{RH}=$ Partially ordered role hierarchy. $\mathrm{RH}$ can also be written as follows:

- One subject can have several roles;

- Several subjects can play the same role;

- One role can have multiple permissions;

- One permission can belong to several roles.

Roles are assigned to subjects; a result of which these subjects receive various permissions through roles. RBAC requires exactly such a designation rather than directly assigning permissions to subjects. Otherwise, it leads to difficulty controlling relations between entities and permits. A restrictive rule is imposed on the ability to inherit permissions from opposing roles to achieve proper mode separation. For example, the same person may not be allowed to create an account for someone and then log in under that account.

We use the notation of set theory:

- PA $\subseteq \mathrm{P} \times \mathrm{A}$, in this case, permissions are assigned to the relationship of roles in relation to "manyto-many".

- $\mathrm{SA} \subseteq \mathrm{S} \times \mathrm{R}$, in this case, the subjects are assigned to the relationship of roles and subjects in relation to "many-to-many".

$-\mathrm{RH} \subseteq \mathrm{R} \times \mathrm{R}$.

A subject can have multiple, simultaneous sessions with different permissions. The use case diagram of working with IDSS is given in Fig. 1. 


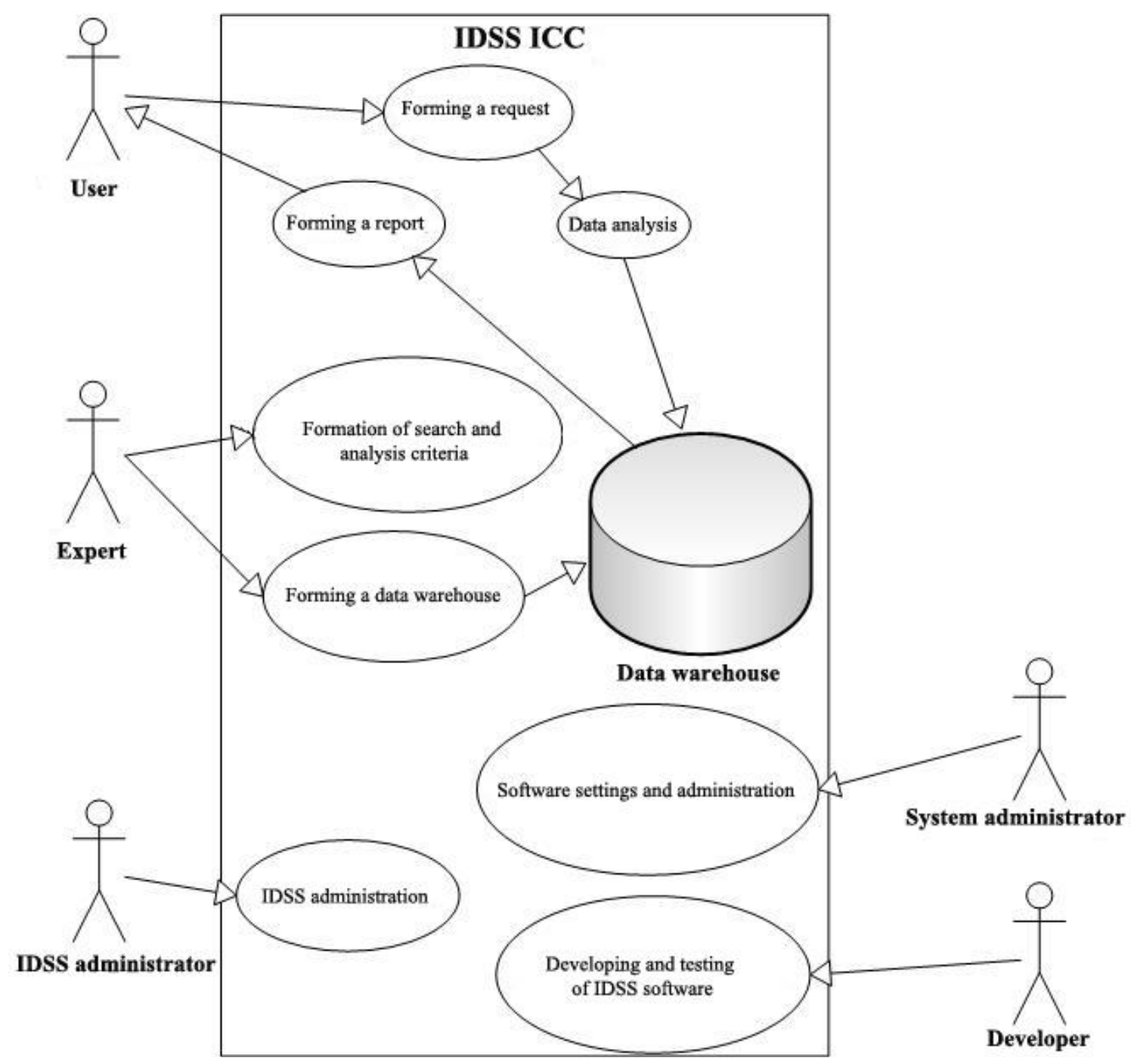

Fig. 1. The use case diagram of working with IDSS.

The authors suggest developing and using IDSS based on client-server architecture. For example, the well known Privat24 provides access to the system through both a web version and mobile applications for Android and iOS [10]. The system can be accessed via the web version using one-time dynamic passwords. After reviewing the scheme proposed by the authors in [3], we decided to remove from the IDSS ICC scheme such elements as users and external data sources. We also decided to make these elements independent of the system and organize communication between them through appropriate software interfaces. The work of information system users was also improved, adding to the previous work [3] categories such as administrators (system, security, web resource, etc.), developer and system owner. Schematically, the system is shown in Fig. 2. 


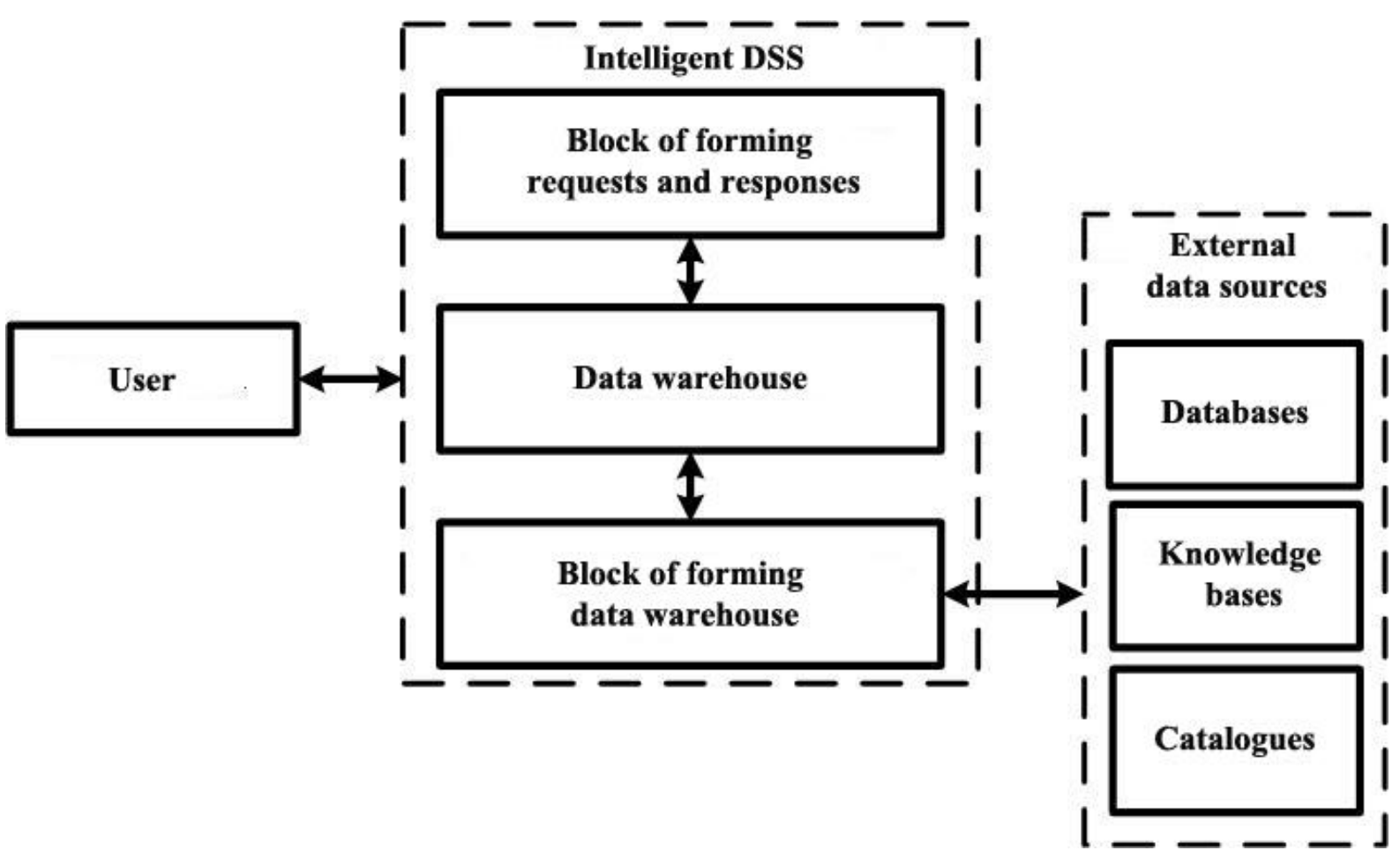

Fig. 2. Simplified schematic representation of IDSS ICC.

The following personnel are suggested to service the system:

- system administrator and security administrator;

- web server administrator;

- IDSS administrator (working with databases and data storage);

- user technical support.

Since data security issues are very important, the authors propose the implementation of IDSS ICC in accordance with the Law on Information Protection in Information and Telecommunication Systems [11], ND TZI 3.7-003-05 "The order of works on the creation of a complex system to protect data in information and telecommunication systems" [12] and ND TZI 3.7-001-99 "Guidelines for the development of terms of reference for the creation of a comprehensive information security system in an automated system" [13].

Typical order scenario (simplified).

1. The user - a person who, in the process of identification, needs the help of IDSS and chooses the most convenient software client (website, mobile application);

2. Using the selected client, the user enters the criteria for searching and analyzing the identification object in the appropriate fields;

3. Having performed the input of initial data, the user transmits the request ("block of requests and responses");

4. IDSS receives search and analysis criteria, then processes them to form a query to the data warehouse ("block of requests and responses").

5. According to the criteria entered, the data is searched (the block "data warehouse").

6. As a result of the search there may be several options. The first option is that the information is available and fully satisfies the request. The second is that the information is available but does not fully satisfy the request. The third option is that there is no information about the identification object in the data warehouse;

7. In the first option (in \#6 above), through the "query and response generation unit" the system issues a report which indicates the degree of probability and refers to which sources the conclusion/conclusions was/were made about the results of the particular object analysis of the ICC project.

8. In the cases of options 2 and 3 (\#6 above), the system asks the user to make a request to external sources of information through the "block to form the data warehouse", but this may require additional time and resources. Futhermore, this data will not be checked by an expert.

9. Output and, if necessary, printing of the report for further processing by the user. 
Conclusions and prospects for further research. The authors analyzed the problems associated with the development of a conceptual model of IDSS ICC as well as the solutions used. The results obtained allow us to draw the following conclusions:

- The problem area is a very wide and poorly studied field of research;

- The creation of IDSS models is a complex task which leads to such issues as data analysis and processes, artificial intelligence systems, organization of databases and data warehouses, software and data security issues;

- Defining criteria for analysis and identification in the creation of IDSS to support multicriteria solutions in a complex information environment is an urgent and difficult task.

It should also be noted that in order to address certain issues (for example, to organize a comprehensive information security system in the information and telecommunications system where the IDSS is located) it is necessary to involve relevant specialists and consider this issue in separate works.

\section{References}

1.Martynenko A., Moroz B., Gulina I. "Intelligent decision support system for the identification of cultural values". IV AllUkrainian scientific-practical conference "Prospective areas of modern electronics, information and computer systems (MEICS2019)". Dnipro, November 27-29, 2019

2.A. Martynenko, B Moroz, I Gulina "Data repositories of the decision support system for the identification of cultural values" XV International Conference on the use of information technology in education, science and industry. Dnipro, December 56,2019

3.Martynenko A., Moroz V., \& Nulina I. (2020). An intelligent decision support system for cultural property identification. COMPUTER-INTEGRATED TECHNOLOGIES: EDUCATION, SCIENCE, PRODUCTION, (39), 78-82.

4.Decision support systems - [Electronic resource] // Access mode: http://bourabai.kz/tpoi/dss.htm

5.Kalashnikova O. Comparative analysis of international and Ukrainian systems of registration and identification of cultural values / OL Kalashnikova // Customs security. - 2013. - № 2. - P. 70-75. - [Electronic resource] // Access mode: http://nbuv.gov.ua/UJRN/mb_2013_2_12.

6.Kalashnikova O. Standardization of artifact cataloging as a means of preserving cultural heritage in conditions of armed conflict. History and theory of law. Legal position, № 1 (16), 2016

7.Kalashnikova O. Legal consequences of imperfect description and accounting of museum collections. International law and the law of the European Union. Actual problems of domestic jurisprudence № 2. Volume 2. 2018 - [Electronic resource] // Access mode: http://apnl.dnu.in.ua/2_2018/tom_2/32.pdf

8.Ferraiolo D., Kuhn D. (October 1992). 15th National Computer Security Conference: 554-563.

9.Sandhu R., Coyne E.J., Feinstein H.L., Youman C.E. (August 1996). IEEE Computer (IEEE Press) 29 (2): 38-47.

10. Wikipedia. Privat24. - [Electronic resource] // URL: https://uk.wikipedia.org/wiki/Приват24

11. Law on protection of information in information and telecommunication systems. - [Electronic resource] // Access mode: https://zakon.rada.gov.ua

12. ND TZI 3.7-003-05 "The order of works on the creation of a complex system to protect data in information and telecommunication systems". - [Electronic resource] // Access mode: http://www.dsszzi.gov.ua/control/uk/publish/article?art_id=46074\&cat_id=38835

13. ND TZI 3.7-001-99 "Guidelines for the development of terms of reference for the creation of a comprehensive information security system in an automated system". - [Electronic resource] // Access mode: http://www.dsszzi.gov.ua/dsszzi/control/uk/doccatalog/list?currDir=42271

\section{Список бібліографічних посилань}

1. А.А. Мартиненко, Б.І. Мороз, І.Г. Гуліна «Інтелектуальна система підтримки прийняття рішень ідентифікації культурних цінностей». IV Всеукраїнська науково-практична конференція «Перспективні напрямки сучасної електроніки, інформаційних і комп'ютерних систем (MEICS-2019)». Дніпро, 27-29 листопада 2019 р.

2. А.А. Мартиненко, Б.І. Мороз, І.Г. Гуліна «Сховища даних системи підтримки прийняття рішень ідентифікації культурних цінностей» XV міжнародна конференція з проблем використання інформаційних технологій в освіті, науці та промисловості. Дніпро, 5-6 грудня 2019 р.

3. Martynenko A., Moroz B., \& Hulina I. (2020). An intelligent decision support system for cultural property identification. COMPUTER-INTEGRATED TECHNOLOGIES: EDUCATION, SCIENCE, PRODUCTION, (39), 78-82.

4. Системы поддержки принятия решений - [Електронний ресурс] // Режим доступу: http://bourabai.kz/tpoi/dss.htm

5. Калашникова О.Л. Порівняльний аналіз міжнародної та української систем реєстрації та ідентифікації культурних цінностей / О. Л. Калашникова // Митна безпека. - 2013. - № 2. - С. 70-75. - [Електронний ресурс] // Режим доступу: http://nbuv.gov.ua/UJRN/mb_2013_2_12.

6. Калашникова О.Л. Стандартизація каталогізації артефактів як засіб збереження культурної спадщини в умовах збройного конфлікту. Історія та теорія права. Правова позиція, № 1 (16), 2016

7.Калашникова О.Л. Правові наслідки недосконалості опису та обліку музейних колекцій. Міжнародне право та право європейського союзу. Актуальні проблеми вітчизняної юриспруденції № 2. Том 2. 2018 - [Електронний ресурс] // Режим доступу: http://apnl.dnu.in.ua/2_2018/tom_2/32.pdf

8.Ferraiolo D.F., Kuhn D.R. (October 1992). 15th National Computer Security Conference: 554-563.

9.Sandhu R., Coyne E.J., Feinstein H.L., Youman C.E. (August 1996). IEEE Computer (IEEE Press) 29 (2): 38-47.

10. Wikipedia. Privat24. - [Електронний ресурc] // URL: https://uk.wikipedia.org/wiki/Приват24 
11. ЗУ Про захист інформації в інформаційно-телекомунікаційних системах. - [Електронний ресурс] // Режим доступу: https://zakon.rada.gov.ua

12. НД ТЗІ 3.7-003-05 "Порядок проведення робіт із створення комплексної системи захисту інформації в інформаційно-телекомунікаційній системі". - 2 [Електронний доступу:http://www.dsszzi.gov.ua/control/uk/publish/article?art_id=46074\&cat_id=38835

13. НД ТЗІ 3.7-001-99 "Методичні вказівки щодо розробки технічного завдання на створення комплексної системи захисту інформації в автоматизованій системі". - [Електронний ресурс]/Режим доступу: http://www.dsszzi.gov.ua/dsszzi/control/uk/doccatalog/list?currDir=42271 